\title{
Інна ІЛЛівна СТРЕЛЬЧЕНКО
}

кандидат економічних наук, доцент, докторант кафедри економіко-математичного моделювання, ДВНЗ «Київський національний економічний університет імені Вадима Гетьмана»

E-mail: iistrelchenko@gmail.com

\section{КОНЦЕПТУАЛЬНІ ЗАСАДИ МАКРОПРОГНОЗУВАННЯ НА ОСНОВІ СИСТЕМИ НЕЙРОННИХ МЕРЕЖ}

Стрельченко, I. І. Концептуальні засади макропрогнозування на основі системи нейронних мереж [Текст] / Інна Іллівна Стрельченко // Економічний аналіз: зб. наук. праць / Тернопільський національний економічний університет; редкол.: О. В. Ярощук (голов. ред.) та ін. - Тернопіль: Видавничо-поліграфічний центр Тернопільського національного економічного університету «Економічна думка», 2017. - Том 27. № 2. - C. 68-73. - ISSN 1993-0259.

\section{Анотація}

Bступ. В умовах прискорених темпів інтеграції світових фінансових ринків, зростання швидкості обміну інформацією та масштабного переходу до електронних грошей важливою задачею стає прогнозування сценаріїв розвитку економіки в умовах різких змін зовнішнього середовища, зокрема під час світової фінансової кризи.

Мета. Розробити та обгрунтувати концептуальні засади макропрогнозування на основі системи нейронних мереж в умовах наростання нелінійності оточуючого середовища.

Метод (методологія). Методологічним підгрунтям стало застосування системного аналізу, комплексних підходів, що базуються, з одного боку, на принципах економічної теорії, а з іншого - на концептуальних засадах економіко-математичного моделювання процесів в економіці та фінансах.

Результати. у роботі обгрунтовано використання системи нейронних мереж у задачі макропрогнозування поведінки економічних систем у кризових умовах; визначено перелік показників, що сформують навчальну вибірку для моделювання; побудовано базову функціональну модель інформаційної технології процесу прогнозування.

Ключові слова: нейронна мережа; кластеризація; мережа Кохонена; прогнозування; фінансова криза; економічна безпека.

\section{Inna Illivna STRELCHENKO}

PhD in Economics,

Associate Professor,

Doctoral Student,

Department of Economic Mathematic Modeling,

Kyiv National Economic University named after Vadym Hetman

E-mail: iistrelchenko@gmail.com

\section{CONCEPTUAL BASES OF MACRO PREDICTION ON THE BASIS OF THE NEURAL NETWORKS SYSTEMS}

\begin{abstract}
(C) Інна Іллівна Стрельченко, 2017
\end{abstract}

Introduction. Under the conditions of accelerated integration of global financial markets, the growth of information exchange speed and large-scale transmission of electronic money, the forecasting of economy scenarios under a sharp change in the environment, particularly during the global financial crisis becomes an important task. Purpose. The aim of the research is to develop and substantiate the conceptual principles of macro-prediction on the basis of the neural networks system in conditions of increasing non-linearity of the environment.

Method (methodology). The use of system analysis, integrated approaches which are based on the principles of economic theory, on the one hand, and, on the other, on the conceptual basis of economic and mathematical modeling of economics and finances processes, have become the methodological basis of the research.

Results. The use of the neural networks system in the task of macro prediction of the economic systems behavior under the crisis conditions has been justified. It has been definited the list of indicators that formed a training 
sample for simulation. The basic functional model of information technology of the forecasting process has been constructed.

Keywords: neural network; clustering; Kohonen network; forecasting; financial crisis; economic security.

\section{Вступ}

Інтеграційні процеси у фінансовій та торгівельній сферах є однією з характерних рис сучасної світової економіки. Експоненційне зростання масштабів, географічного поширення, швидкості здійснення грошових операцій та обміну інформацією несуть у собі нові виклики національним економікам. Зокрема, методика оцінки національної економічної безпеки повинна враховувати можливі сценарії поведінки основних показників функціонування економіки під час виникнення світових фінансових криз [1]. Так, наприклад, під час кризи 2007-2009 pр., економіка України, котра не була першоджерелом її виникнення, постраждала у підсумку чи не найбільше. Було зафіксоване скорочення економіки в першому кварталі 2009 року на $21,1 \%$, після зменшення на 8 \% у попередньому кварталі. Стрімко зросла вартість державних облігацій - на 733 базисних пункти, фондовий ринок впав на $25 \%$, у першому півріччі 2008 року інфляція скала 15,5 \%. Курс гривні до долара США впав на 60 \% на тлі скорочення експорту та відтоку іноземних інвесторів з ринків, що розвиваються [2].

Зважаючи на це, в роботі запропоновано та обгрунтовано концептуальні положення використання системи нейронних мереж для макропрогнозування в умовах наростання нелінійностей навколишнього середовища.

Проблематиці передбачення наслідків кризових явищ в економіці присвячена велика кількість досліджень та публікацій [3-8]. Попри різні погляди щодо механізмів формування кризових явищ, першоджерелом їх виникнення дослідники визначають дисбаланси в розвитку окремих сфер функціонування економіки.

Модель, запропонована в роботі Кругмана, визначає головною причиною кризи дефіцит бюджету, котрий фінансується за рахунок нарощування державного боргу [5]. Це згодом призводить до значного скорочення золотовалютних резервів, і як тільки рівень резервів сягає критичної позначки, Центральний банк країни виявляється більш не в змозі утримувати фіксований курс. Що неминуче призводить до зміни валютного режиму внаслідок спекулятивної атаки на валюту.

Частина досліджень доводить, що високий рівень державного боргу збільшує витрати утримування валютного курсу, провокуючи тим самим виникнення спекулятивних атак [8]. Оскільки очікування щодо девальвації закладені в номінальній відсотковій ставці, то зростаючі витрати 3 обслуговування боргу, які здорожують утримування фіксованого курсу, можуть привести до рішення про зміну наявного валютного режиму. Національний банк не буде зацікавлений у тому, щоб захищати фіксований курс шляхом збільшення ставок відсотків, оскільки це може спровокувати банківську кризу (внаслідок розбіжності терміновості і збільшення ризику в період рецесії).

Деякі концепції намагаються пояснити нестійкість економік, що розвиваються, до кризових процесів труднощами, котрі пов'язані з виплатою і обслуговуванням їх зовнішнього боргу. Проблема нестабільності пояснюється тим, що країнам важко деномінувати свої зобов'язання в одиницях, які краще відображають їх платоспроможність, серед яких можна назвати національну валюту або споживчий кошик. У такому випадку валютний розрив у межах платіжного балансу може бути наслідком неадекватної політики в галузі управління зовнішнім боргом або нездатності країн, що розвиваються, позичати в національній валюті [6-7].

Попри значне зацікавлення цією проблемою поки що не існує універсального дієвого механізму макропрогнозування поведінки економічних систем в умовах наростання нелінійностей зовнішнього середовища.

\section{Мета і завдання статті}

Метою нашого дослідження $\epsilon$ розроблення та обгрунтування концептуальних засад макропрогнозування на основі системи нейронних мереж в умовах наростання нелінійності оточуючого середовища.

Мета визначила наступні завдання:

- обгрунтувати використання системи нейронних мереж у задачі макропрогнозування поведінки економічних систем у кризових умовах;

- визначити перелік показників, що сформують навчальну вибірку для моделювання;

- побудувати базову функціональну модель інформаційної технології процесу прогнозування. 


\section{Виклад основного матеріалу дослідження}

Задача макропрогнозування поведінки динамічних об'єктів і систем в умовах різких збурень навколишнього середовища вимагає використання нелінійних моделей. 3 іншого боку, механізм ï опису має бути інтуїтивно зрозумілим та мати чітку економічну інтерпретацію. Крім цього, при виборі інструментарію потрібно врахувати об’єктивні обмеження на розмір вихідної вибірки. Це пов'язано 3 неоднорідністю У результаті чого більш-менш прийнятна база даних для моделювання може бути сформована на основі світової фінансової кризи 2007-2009 рр., коли більшість країн почали подавати економічну статистику відповідно до методик розрахунку Міжнародного валютного фонду.

Крім цього, розробка універсального алгоритму ускладнюється розумінням того, що минулі фінансові кризи мали відмінні рушійні сили, джерела виникнення, канали розповсюдження та вплив на економіки країн світу. Це підводить нас до думки, що термін «макропрогнозування» в цьому випадку не розглядається як спроба передбачення «точки кипіння» економіки. Проте для вчасної корекції економічної політики це не $є$ першочерговим завданням. На нашу думку, важливо однозначно визначити залежність між набором вхідних змінних та індикативними границями коливань макропоказників, котрі $\epsilon$ найчутливішими до різких змін в економіках країн-партнерів: ВВП, валютний курс, обсяг золотовалютних резервів та ін.

Відповідно до таких міркувань у роботі запропоновані та обгрунтовані концептуальні положення використання системи нейронних мереж для розв'язання поставленої задачі.

Нейронна мережа є математичним інструментарієм, що реалізує ідею обробки інформації за принципом нервової системи. Навчена нейронна мережа дає можливість будувати наближення для широкого класу залежностей між вхідними параметрами та результатом [9-13]. Серед переваг використання нейронних мереж потрібно відзначити відсутність необхідності у суворій математичній специфікації моделі (для адекватного опису об’єкта дослідження, що відноситься до класу слабоформалізованих процесів, дана властивість $є$ особливо цінною), стійкість до змін зовнішніх умов та гарні результати роботи з великим обсягом суперечливої і неповної інформації.

Оберемо набір вхідних індикаторів для моделювання. Відповідно до результатів наявних досліджень з даної проблематики, вони повинні кількісно відображати дисбаланси у розвитку економіки. Проаналізувавши доробок зарубіжних та вітчизняних фахівців у цьому напрямку, в межах розв'язуваної задачі, пропонуємо використати як індикатори наступні показники:

1. Співвідношення грошового агрегату М2 до золотовалютних резервів, \% (відповідно до стандартів МВФ, джерело - дані міжнародної статистики МВФ (IFS)).

2. Спред реальної відсоткової ставки всередині країни до аналогічного показника за кордоном, \% пунктів (джерело - дані міжнародної статистики MBФ (IFS) та LIBOR).

3. Грошовий мультиплікатор M2, \% (відповідно до стандартів МВФ, джерело - дані міжнародної статистики МВФ (IFS)).

4. Сальдо поточного рахунку платіжного балансу, \% до ВВП (відповідно до стандартів МВФ, джерело дані міжнародної статистики МВФ (IFS)).

5. Індекс тиску на валютному ринку (IEMP) обчислюється за формулою (1) [14]:

$$
E M P I_{i, t}=\frac{1}{\sigma_{e}} \cdot \frac{\Delta e_{i, t}}{e_{i, t}}-\frac{1}{\sigma_{r e s}} \cdot\left(\frac{\Delta r e s_{i, t}}{\operatorname{res}_{i, t}}-\frac{\Delta r e s_{U S t}}{r_{U S t}}\right)+\frac{1}{\sigma_{i}}\left(i_{i, t}-i_{U S t}\right),
$$

де $E M P I_{i, t}$ - індекс тиску на валютному ринку для країни $i$ в період $t$;

$e_{i, t}-$ обмінний курс валюти країни $i$ до валюти базової країни за період часу $t$;

$\sigma_{e}$ - стандартне відхилення обмінного курсу $\left(\Delta e_{i, t} / e_{i, t}\right)$;

$r_{i, t}$ - міжнародні валютні резерви країни $i$ в період $t$;

$\sigma_{r e s}$ - стандартне відхилення різниці між $\left(\Delta r e s_{i, t} / \operatorname{res}_{i, t}\right)$ та $\left(\Delta r e s_{U S t} / \operatorname{res}_{U S t}\right)$;

$i_{i, t}$ - номінальна ставка відсотка в країні за період часу $t$;

$i_{U S t}$ - номінальна ставка відсотка базової країні $i$ за період часу $t$;

$\sigma_{i}$ - стандартне відхилення різниці $\left(i_{i, t}-i_{U S t}\right)$;

$r e s_{i, t}$ - співвідношення міжнародних валютних резервів до грошової маси (М1) країни $i$ в період $t$.

6. Фондовий індекс, \% до попереднього періоду (за даними відповідної фондової біржі).

7. Індекс міжнародної фінансової інтеграції (IFI), \% до ВВП (2):

іноземні активи + фінансові зобов' язання країни $B В \Pi$ 
Відповідно до теоретичної концепції, котру пропонує автор, побудована та навчена нейронна мережа на основі динаміки обраних індикаторів за певний проміжок часу (до початку кризи) повинна визначати можливі сценарії поведінки економіки досліджуваної країни. Під поведінкою в даному випадку будемо розуміти зміни макропоказників, що $є$ найчутливішими до різких змін в економіках країн-партнерів. Це:

- ВВП, у \% до попереднього періоду;

- $\quad$ реальний обмінний курс, у \% до попереднього періоду;

- обсяг золотовалютних резервів, у \% до попереднього періоду;

- міжнародна інвестиційна позиція, у \% до попереднього періоду;

- $\quad$ вартість державних облігацій, у \% до попереднього періоду.

Для практичної реалізації процесу навчання нейронної мережі потрібно мати еталонну систему класів, що розбиватиме статистичну сукупність вихідних даних на групи країн. Кожна група характеризуватиметься подібністю динаміки наведених макропоказників під час проходження кризи. У такому випадку мінімальні коливання показників всередині групи можна інтерпретувати як найм'якіший сценарій розвитку; максимальні коливання відповідатимуть найжорсткішому варіанту; найбільш вірогідна динаміка буде пов'язана з середніми значеннями по групі.

Для цієї задачі відсутня така еталонна система класів. Отже, потрібно її створити. 3 цією метою пропонуємо використати нейронну мережу Кохонена.

Мережі Кохонена - це один з різновидів нейронних мереж, що принципово відрізняються від інших, оскільки використовують неконтрольоване навчання. Під час такого навчання навчальна вибірка складається лише зі значень вхідних змінних, в процесі навчання немає порівняння виходів нейронів 3 еталонними значеннями. Можна сказати, що така мережа навчається розуміти структуру даних [10].

У межах нашого дослідження мережі Кохонена володіють набором переваг, порівняно 3 іншими методами кластеризації, зокрема:

- доведено ефективно працюють в умовах невеликого обсягу навчальної вибірки;

- реалізують концепцію «навчання без учителя»;

- мають інтуїтивно зрозумілу та високоякісну графічну візуалізацію.

Враховуючи це, побудуємо базову функціональну модель інформаційної технології процесу макропрогнозування (рис. 1).

\section{Висновки та перспективи подальших розвідок}

У результаті проведеної роботи розроблено концептуальні положення макропрогнозування динаміки економічних систем під час наростання нелінійностей зовнішнього середовища. Визначено вимоги до математичного інструментарію для побудови відповідної економіко-математичної моделі. Обгрунтовано використання системи нейронних мереж для практичної реалізації розробленої методики. Побудовано базову функціональну модель інформаційної технології процесу макропрогнозування на основі системи нейронних мереж.

Розроблені концептуальні положення та принципи моделювання можуть бути застосовані в задачах моделювання динамічних систем - економічних (для прогнозування можливих сценаріїв динаміки макропоказників в умовах розповсюдження кризових явищ); медичних (для передбачення різких змін у функціонуванні життєво важливих функцій організму - інфарктів, інсультів і т. п.).

\section{Список літератури}

1. Про затвердження Методичних рекомендацій щодо розрахунку рівня економічної безпеки України № 1277 від 29.10.2013 p. [Електронний ресурс]. - Режим доступу: http://search.ligazakon.ua/__doc2.nsf/link1/ME131588.html.

2. Офіційний сайт Державного комітету статистики [Електронний ресурс]. - Режим доступу: http://www.ukrstat.gov.ua.

3. Hicks, J. R. Value and Capital: Growth Model / J. R. Hicks // Oxford University Press. - 1959. - Vol. 26 (3). P. 159-173.

4. Kondrat'ev, N. D. Problemy ekonomicheskoi dinamiki / N. D. Kondrat'ev // - Moscow, Russia: Ekonomika. 1989. $-526 \mathrm{p}$.

5. Krugman, P. A Model of Balance-of-Payments Crises / P. Krugman // Journal of Money, Credit and Banking. 1979. - Vol. 1. - Is. 3. - P. 311-325. 
ВВП, реальний обмінний курс, золотовалютні резерви, міжнародна інвестиційна позиція, вартість державних облігацій

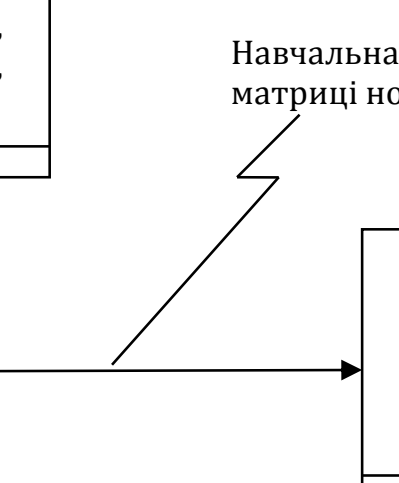

Визначення еталонної системи класів на основі нейронної

Первинна обробка даних мережі Кохонена

Еталонна система

класів для

прогнозування

\begin{tabular}{|lrr}
\hline \multicolumn{2}{|l}{ Співвідношення } & грошового \\
агрегату М2 до золотовалютних \\
резервів, спред & реальної \\
відсоткової & ставки & всередині \\
країни до аналогічного показника \\
за кордоном, & грошовий \\
мультиплікатор M2, сальдо \\
поточного рахунку платіжного \\
балансу, індекс & тиску на \\
валютному ринку, фондовий \\
індекс, індекс міжнародної \\
фінансової інтеграції, частка \\
експорту сировинних ресурсів
\end{tabular}
експорту сировинних ресурсів

\section{Рис. 1. Базова функціональна модель інформаційної технології процесу макропрогнозування на} основі системи нейронних мереж

6. Garber, M. The Operation and Collapse of Fixed Exchange Rate Regimes / M. Garber, E.O. Svensson // Handbook of International Economics. - 1995. - Vol. 3. - P. 1865-1911.

7. Girton, L. A Monetary Model of Exchange Market Pressure Applied to Postwar Canadian Experience / L. Girton, D. Roper // American Economic Review - 1977. - Vol. 67. - P. 537-548.

8. Obstfeld, M. Rational and Self-Fulfilling Balance-of-Payments Crises / M. Obstfeld // American Economic Review. - 1986. - Vol. 76. - P. 72-81.

9. Дюк, В. Data mining: учебный курс / В. Дюк, А. Самойленко. - СПб: Питер, 2001. - 368 с.

10. Kohonen, T. Self-organizing maps / T. Kohonen. - New-York: Springer, 2001. -501 p.

11. Уоссермен, Ф. Нейрокомпьютерная техника: Теория и практика / Ф. Уоссермен. - М.: Мир, 1992. $240 \mathrm{c}$.

12. Бодянский, Е. В. Искусственные нейронные сети: архитектура, обучение, применение / Е. В. Бодянский, О. Г. Руденко. - Харьков: ТЕЛЕТЕХ, 2004. - 372 с.

13. Grossberg S. Some networks that can learn, remember and reproduce any number of complicated space-time patterns / S. Grossberg // Journal of Mathematics and Mechanics. - 1969. - Vol. 19. - No. 1. - P. 53-91.

14. Kaminsky, G. Leading indicators of currency crises / G. Kaminsky, S. Lizondoб C. Reinhart // IMF Stuff Papers, 1998. - Vol. 45. - P. 1-48. 


\section{References}

1. On Approval of Methodological Recommendations for Calculating the Level of Economic Security of Ukraine [E-Reader Version]: Retrieved from: http://search.ligazakon.ua/1_doc2.nsf/link1/ME131588.html.

2. The official website of the State Statistics Committee [E-Reader Version]: Retrieved from: http://www.ukrstat.gov.ua/.

3. Hicks, J. R. (1959). Value and Capital: Growth Model. Oxford University Press.

4. Kondrat'ev, N. D. (1989). Problemy ekonomicheskoi dinamiki. Moscow, Russia: Ekonomika.

5. Krugman, P. (1979). A Model of Balance-of-Payments Crises. Journal of Money, Credit and Banking, 1(3), 311-352.

6. Garber, M., \& Svensson, E. O. (1995). The Operation and Collapse of Fixed Exchange Rate Regimes. Handbook of International Economics, 3, 1865-1911.

7. Girton, L., \& Roper, D. A. (1977). Monetary Model of Exchange Market Pressure Applied to Postwar Canadian Experience. American Economic Review, 67, 537-548.

8. Obstfeld, M. (1986). Rational and Self-Fulfilling Balance-of-Payments Crises. American Economic Review, 76, $72-81$.

9. Duk, V. \& Samoilenko, A. (2001). Data Mining: study course. St. Petersburg: Peter.

10. Kohonen T. (2001). Self-organizing maps. New-York: Springer.

11. Wosserman F. (1992) Neurocomputer Technology: Theory and Practice. Moscow: Mir.

12. Bodyanskiy E. \& Rudenko O. (2004). Artificial Neural Networks: Architecture, Training, Application. Kharkiv: TELETEKH.

13. Grossberg S. (1969). Some networks that can learn, remember and reproduce any number of complicated space-time patterns. Journal of Mathematics and Mechanics, 19(1), 53-91.

14. Kaminsky G. \& Lizondo S. \& Reinhart C. (1998). Leading indicators of currency crises. IMF Stuff Papers, 45, $1-48$.

\section{Стаття надійшла до редакції 19.05.2017 р.}

